\title{
Is responsible investing ethical?
}

\author{
S. Viviers* and J.K. Bosch \\ Department of Business Management, Nelson Mandela Metropolitan University, \\ PO Box 77000, Port Elizabeth 6031, Republic of South Africa \\ suzette.viviers@nmmu.ac.za; johan.bosch@nmmu.ac.za
}

\section{E.v.d.M. Smit}

University of Stellenbosch Business School, PO Box 610, Bellville 7535, Republic of South Africa evdms@usb.sun.ac.za

\author{
A. Buijs \\ Utrecht School of Economics, University of Utrecht, \\ Janskerkhof 12, 3512 BL Utrecht, The Netherlands \\ a.buijs@econ.uunl
}

Received March 2008

\begin{abstract}
A growing number of investors, globally and in South Africa, are embracing the concept of Responsible Investing (RI). In essence RI refers to a combination of investment strategies that integrate ethical as well as environmental, social and corporate governance considerations into investment analysis and decision making processes. Given the growing influence that investors are exerting on corporate decision making, the purpose of this paper was to position RI within an appropriate ethical framework. It is shown that RI constitutes a form of moral investing as responsible investors express a concern for universal principles which exceed the prescriptions of the law. The practice of RI was further contextualised in relation to seven approaches to ethical reasoning, namely ethical egoism, utilitarianism, deontological ethics, the ethics of care, virtue theory, the conventional approach to ethics as well as emotivism. From the evidence presented, it seems as if responsible investors in South Africa give preference to the principles underlying deontological ethics as well as the ethics of care (particularly with regard to the protection of human rights and equality as well as the promotion of distributive and compensatory justice).
\end{abstract}

*To whom all correspondence should be addressed.

\section{Introduction}

A growing number of investors, globally and in South Africa, are embracing the concept of Responsible Investing (RI) (Sullivan \& Mackenzie, 2006:3; De Jongh, Ndlovu, Coovadia \& Smith, 2007:3). In essence RI refers to a combination of investment strategies that integrate ethical as well as environmental, social and corporate governance (ESG) considerations into investment analysis and decision making processes (United Nations, 2006:1).

This phenomenon has been described under various names such as 'ethical investing', 'green investing', 'sustainability investing', 'directed investing' and 'socially responsible investing' (White, 1995:323; Cowton, 1998:181). In the South African context reference is also frequently made to 'targeted investing' (Cranston, 2004; Petersen, 2005).

Empirical evidence shows that RI in developed economies is gradually moving from a fringe investment strategy to a mainstream consideration (Knoll, 2002:681; Schueth, 2003:189). A report by the US Social Investment Forum for example shows that $\$ 2.29$ trillion or nearly one out of every ten dollars under professional management in the USA in 2005 was invested on the basis of ethical and ESG criteria (Mitchell \& Larson, 2006:2).This statistics represents a 260 percent absolute increase in RI over the past decade. Strong growth rates have also been recorded in the United Kingdom, Europe and the Asia-Pacific region (Guay, Doh \& Sinclair, 2004:126; Holland, 2002:49).

Although the first RI funds in South Africa were already established in 1992, the local RI sector has not been able to attract the same level of funding as compared with its international counterparts. It is estimated that only 0.7 percent of assets under professional management in South Africa are invested based on RI principles (Alexander Forbes Asset Consultants Targeted Development Investment Vehicles Manager Watch Survey September 2006, 2006). It should however be noted that this figure excludes multimanagers and private equity funds.

As indicated in Figure 1, RI consists of three prominent strategies, namely screening, shareholder activism and cause-based (targeted) investing. 


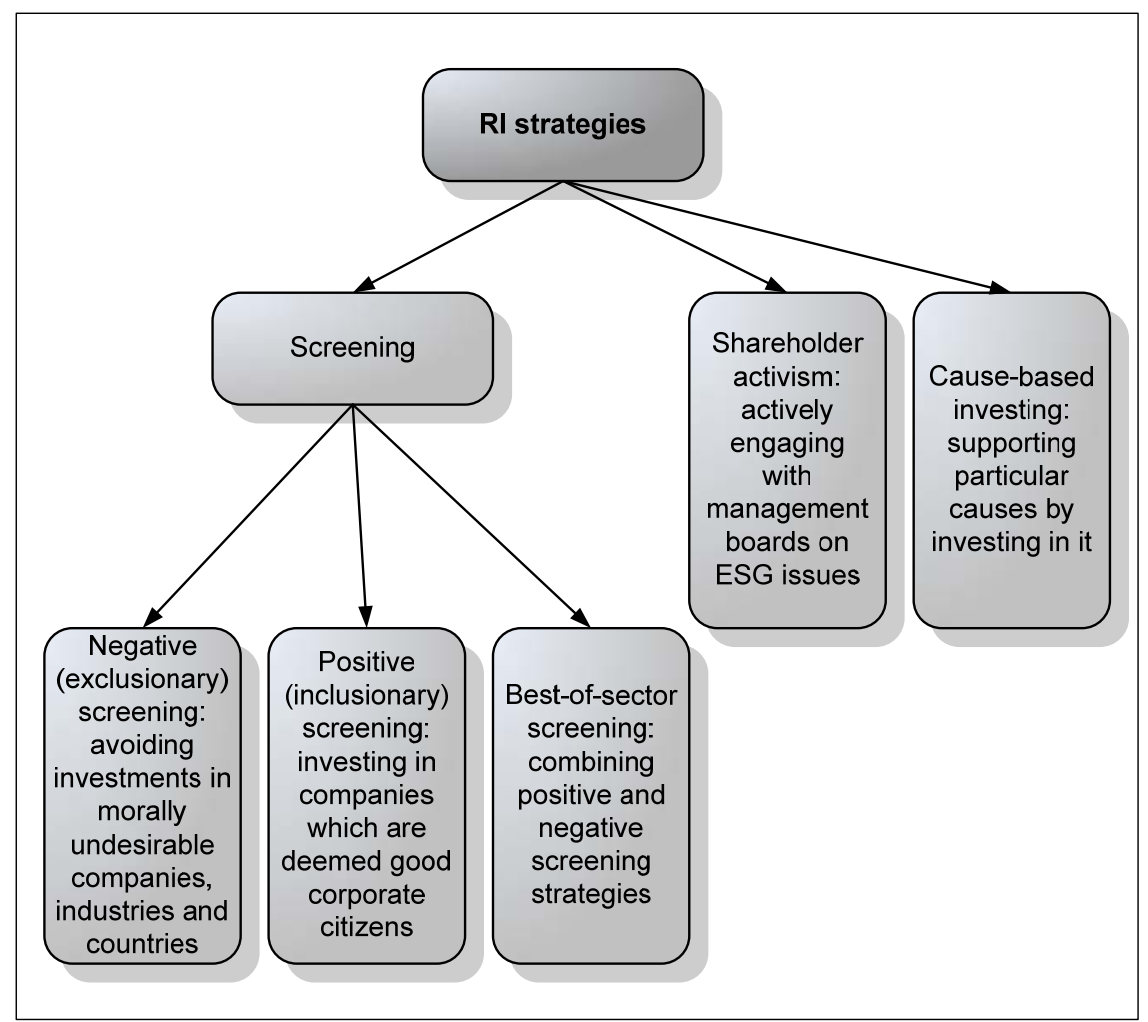

Figure 1: Prominent RI strategies

Source: Researchers' own construct.

Investors who apply negative screens avoid investments in morally undesirable companies, industries and countries. Such investors often base their investment criteria on their religious convictions and hence avoid companies associated with the production and/or sale of tobacco, alcohol, armaments, gambling and pornography. In recent years several Shari'ah or Islamic law compliant funds, which employ exclusionary 'sin' screens, have seen the light, both internationally and in South Africa (Kalideen, 2004; Hussein \& Omran, 2005:105). Investors can also employ positive or inclusionary screens where they invest in companies that are deemed good corporate citizens i.e. companies that value their stakeholders and place a high premium on corporate governance. In South Africa a great deal of emphasis is placed on broad-based Black Economic Empowerment (BBBEE) issues as well as the development of social infrastructure (Viviers, 2007).

Besides screening, responsible investors can also actively engage with management boards on various ESG issues through dialogue, by filing resolutions, voting at annual general meetings and divesting from companies that fail to transform (De Cleene \& Sonnenberg, 2004:5). In South Africa, active shareholders predominantly focus on corporate governance and labour related issues. Finally, cause-based (targeted) investing refers to an investment strategy where investors support particular causes (such as BBBEE or social infrastructural development) by investing in it.
Empirical evidence shows that the majority of local RI funds employ a cause-based (targeted) investment strategy, either on its own or in combination with a positive screening approach (Viviers, 2007).

\section{Problem statement}

As no prior studies have attempted to position RI within an appropriate ethical framework, the authors of this article have set out to do so. It should however be noted that ethical questions are essentially philosophical questions and that there is seldom consensus among philosophers about the answers to such questions. This contribution to the literature on RI is deemed important given the growing influence exerted by investors on corporate decision making.

It should be kept in mind that this research focuses on the ethical decisions made by individual investors. The reason is that they are not restricted by fiduciary duties and investment mandates as in the case of institutional investors. The following discussion furthermore relates to all three RI strategies as highlighted in Figure 1.

\section{Research design and methodology}

The positioning of RI within an appropriate ethical framework evolved from the application of phenomenological data analysis methods which comprise comprehending, synthesising, theorising and recontextualising the issues at stake (Collis \& Hussey, 2003:262). An extensive review of secondary sources was 
undertaken as part of this process. Content analysis was furthermore employed to evaluate the investment objectives of the 43 RI funds established in South Africa over the period 1 June 1992 to 31 March 2006.

In the next section a number of concepts such as ethics, values and morality will be defined. Secondly, a distinction will be drawn between three types of investing, namely immoral, amoral (or ethically indifferent) and moral investing. This will be followed by a presentation of a generic ethical decision making model as well as a number of approaches to ethical decision making.

\section{Defining relevant concepts}

The word 'ethics' is derived from the Greek word ethos (character) and the Latin word mores (customs) which, in combination, describe how individuals choose to interact with one another. Although philosophers occasionally differentiate between ethics and morality, where ethics is seen to be an intellectual reflection on conduct and morality as the actual conduct, no such distinction will be made in this chapter. Such a strict distinction is seldom made in business ethics literature, which serves as the basis for this research.

In the most elementary sense ethics concerns itself with what is good and right in human interaction (Smit \& Cronjè, 1997:490). More specifically, ethics refers to the set of moral principles or values that drive human behaviour (Stevenson, 2005:4). Although not entirely distinct from ethics, values more specifically relate to an individual's concepts of comparative worth, utility and the importance of certain ideas.

Most definitions of ethics involve a consideration of the 'self', 'others' and the notion of 'good'. According to Rossouw (2004:3), all three elements i.e. 'others', 'self' and 'good' should be included in a comprehensive definition of ethics. He argues that the unique nature of ethics would collapse when the notion of 'good' is omitted. It should further be noted that ethics is not merely concerned with the interaction between the 'self' and 'others', but also with the quality of the interaction between the parties involved. A distortion would likewise occur if the 'self' were to be excluded from the definition of ethics. This would occur if an individual were merely concerned about what is good for others, whilst ignoring his/her own interests. This is clearly an unsustainable scenario as most individuals are not able to entirely sacrifice their own needs in favour of others.

Should 'others' be excluded from the definition of ethics, selfish behaviour would manifest itself. Focusing merely on what is good for the 'self' is contrary to the very nature of ethics, which is to ensure the interests the 'self' and 'others'. Rossouw (2004:4) cautions that self-interest should not be confused with selfishness. The latter occurs when an individual knows that his/her behaviour might have a negative effect on others, yet continues to engage in such behaviour. As a result such behaviour is not only selfish but also unethical. If, on the other hand, the individual seeks to serve his/her own interests, while simultaneously caring about the interests of others, his/her behaviour is deemed to be ethical.

By using this threefold definition of ethics, it can be shown that RI indeed reflects ethical decision making on the part of investors. As in the case of mainstream investors, responsible investors are self-interested in that they are generally not willing to sacrifice financial returns in favour of promoting the needs of others. Besides their own needs, responsible investors consider the needs of an array of 'others' such as:

- customers e.g. by excluding businesses which engage in unethical marketing or pricing practices;

- $\quad$ suppliers e.g. by investing in businesses that procure locally;

- employees e.g. by engaging with businesses which have poor occupational health and safety records;

- members of society e.g. by investing in businesses that generate employment opportunities or develop social infrastructure and by excluding businesses that pollute the environment; and

- $\quad$ animals e.g. by engaging with the management boards of pharmaceutical and cosmetic companies that conduct scientific tests on animals.

\section{Investment ethics}

Carroll and Bucholtz (2000:107) identified three types of management ethics which will be adapted and contextualised to the study of RI to reflect three types of investment ethics. As indicated in Table 1 these types include immoral, amoral (or ethically indifferent) and moral investing. Insight into these types of investment ethics will foster a better understanding of the range of behaviours that investors can display, intentionally or unintentionally.

\section{Immoral investing}

Using the concepts immoral and unethical as synonyms, immoral investing can be defined as “...a posture that not only is devoid of ethical principles or precepts but also implies a positive and active opposition to what is ethical" (Carroll \& Bucholtz, 2000:108). As indicated in Table 1, this view of investing holds that an investor's motives are selfish and greedy as the individual only cares about his/her own needs. If an investor is actively opposed to what is regarded as ethical, it implies that he/she knows what is right, yet chooses to do what is wrong. Immoral investors pursue wealth maximisation at all costs and regard the law as a barrier to be overcome in order to accomplish their goals. One example of immoral (and unlawful) investment behaviour is that of insider trading. 
Table 1: Three types of investment ethics

\begin{tabular}{|c|c|c|c|}
\hline & Immoral investing & & Moral investing (RI) \\
\hline Ethical norms & $\begin{array}{l}\text { Investment decisions imply } \\
\text { a positive and active } \\
\text { opposition to what is } \\
\text { ethical. } \\
\text { Decisions are discordant } \\
\text { with acceptable ethical } \\
\text { principles. } \\
\text { An active negation of what } \\
\text { is moral is implied. }\end{array}$ & $\begin{array}{l}\text { The investor is neither immoral nor } \\
\text { moral, but considers investment } \\
\text { decisions to lie outside the sphere to } \\
\text { which moral judgements apply. } \\
\text { May imply a lack of ethical perception } \\
\text { and moral awareness. }\end{array}$ & $\begin{array}{l}\text { Investment decisions conform to high ethical } \\
\text { standards. }\end{array}$ \\
\hline Motives & $\begin{array}{l}\text { Selfish, greedy, caring only } \\
\text { about own needs. }\end{array}$ & $\begin{array}{l}\text { Well intentioned but selfish in the sense } \\
\text { that no consideration is given to the } \\
\text { impact of investment behaviour on } \\
\text { others. }\end{array}$ & $\begin{array}{l}\text { Good. The investor wants to prosper but only } \\
\text { within the constraints of sound ethical } \\
\text { precepts. } \\
\text { Seek enlightened self-interest. }\end{array}$ \\
\hline Goals & $\begin{array}{l}\text { Wealth maximisation at } \\
\text { any price. }\end{array}$ & $\begin{array}{l}\text { Wealth maximisation. No other goals are } \\
\text { considered. }\end{array}$ & $\begin{array}{l}\text { Wealth maximisation within the confines of } \\
\text { legal obedience and ethical standards. }\end{array}$ \\
\hline $\begin{array}{l}\text { Orientation } \\
\text { towards the } \\
\text { law }\end{array}$ & $\begin{array}{l}\text { Legal standards are barriers } \\
\text { that must be overcome to } \\
\text { accomplish goals. }\end{array}$ & $\begin{array}{l}\text { The letter of the law guides ethical } \\
\text { decision making. }\end{array}$ & $\begin{array}{l}\text { Obedience to the letter and spirit of the law. } \\
\text { The law indicates minimal ethical behaviour. } \\
\text { The investor prefers to operate well above } \\
\text { what legislation mandates. }\end{array}$ \\
\hline
\end{tabular}

Source: Adapted from Carroll and Bucholtz (2000:114).

\section{Moral investing}

The antithesis of immoral investing is that of moral investing. Although it is not always clear which ethical standards prevail in a society, moral investors generally strive to uphold these as well as high standards of professional conduct (Carroll \& Bucholtz, 2000:109). In contrast to the selfish motives of immoral investors, moral investors aspire to prosper financially, but only within the confines of legal and ethical precepts. RI investors are clearly moral investors as they consider what is good for themselves and others.

\section{Amoral (ethically indifferent) investing}

A formal definition of 'amoral' refers to decisions or actions which are neither moral nor immoral. It further refers to someone who fails to admit moral distinctions or judgments, who lacks moral sensibility and does not care about right and wrong (Carroll \& Bucholtz, 2000:112). In essence, amoral investing implies that investors are indifferent to ethical or ESG considerations. Amoral investing is however not just a middle position on a continuum between immoral and moral investing but is very different in kind from both of these types of investing.

Two kinds of amoral investors can be distinguished. First there are intentional amoral investors who do not factor ethical considerations into their decisions because they believe investment matters resides outside the sphere to which moral judgments apply. These investors hold on to the old adage which states that "...one should not mix morals with money”. It is important to stress that these investors are neither immoral nor moral. They simply believe that different rules apply to investment decisions than to other realms of life. Whereas Carroll and Bucholtz (2000:112) argue that intentionally amoral managers are a distinct minority in business today, the same cannot be said about amoral investors. This claim is justified when considering the small percentage of responsible investors in financial markets compared with traditional investors (De Cleene \& Sonnenberg, 2004:5).

Like intentional amoral investors, unintentional amoral investors do not think about investments in ethical terms. These investors are merely inattentive to the fact that their decisions and actions may have a negative effect on others. It could be said that these investors lack ethical perception and moral awareness or that they simply find it difficult to see how their investments in particular businesses affect the stakeholders of those businesses.

As shown in Table 1, both types of amoral investors pursue wealth maximisation as a goal but do not cognitively attend to moral issues that may be intertwined with that pursuit. Amoral investors are further guided by the letter of the law when making ethical decisions. Based on the above arguments, it could be claimed that the majority of investors today are amoral investors.

\section{The ethical decision making process}

Bodie, Kane and Marcus (2002:940) outline the typical stages through which investors progress when investing, namely specifying investment objectives, stipulating investment criteria and constraints, formulating an investment policy, implementing decisions as well as monitoring and updating the overall investment portfolio from time to time. Ethical decision making should not be seen as a separate activity, but rather as an integral part within each of these stages. Irrespective of the stage(s) during which moral judgment is required, investors are always faced with a decision making continuum. 
On the one hand of the continuum, the individual's decisions are governed by the laws of a country, for example, investments ought not to be made in businesses operating illegally. At the other extreme no laws are in place (or required) to direct the individual's decisions. Investments could thus be made in any lawfully operating business (Smit \& Cronjè, 1997:490). In between the two extremes, the individual has to evaluate corporate behaviour against one or more ethical approaches in order to make an informed investment decision.

In the area of free choice, investors are accountable only to themselves, whereas on the other end of the continuum, they are fully accountable for complying with a country's prescribed laws. In the area directed by the individual's personal views of morality, accountability merely depends on the norms and standards of which the individual are aware of but which are not enforceable. This type of personal accountability forms the crux of RI and depends to a large extent on the individual's level of moral development.

It should be noted that ethical decision making is a multi-faceted process and although it can be portrayed graphically, as in Figure 2 , such a depiction does not fully capture the reality and complexities associated with ethical or socially responsible decision making.

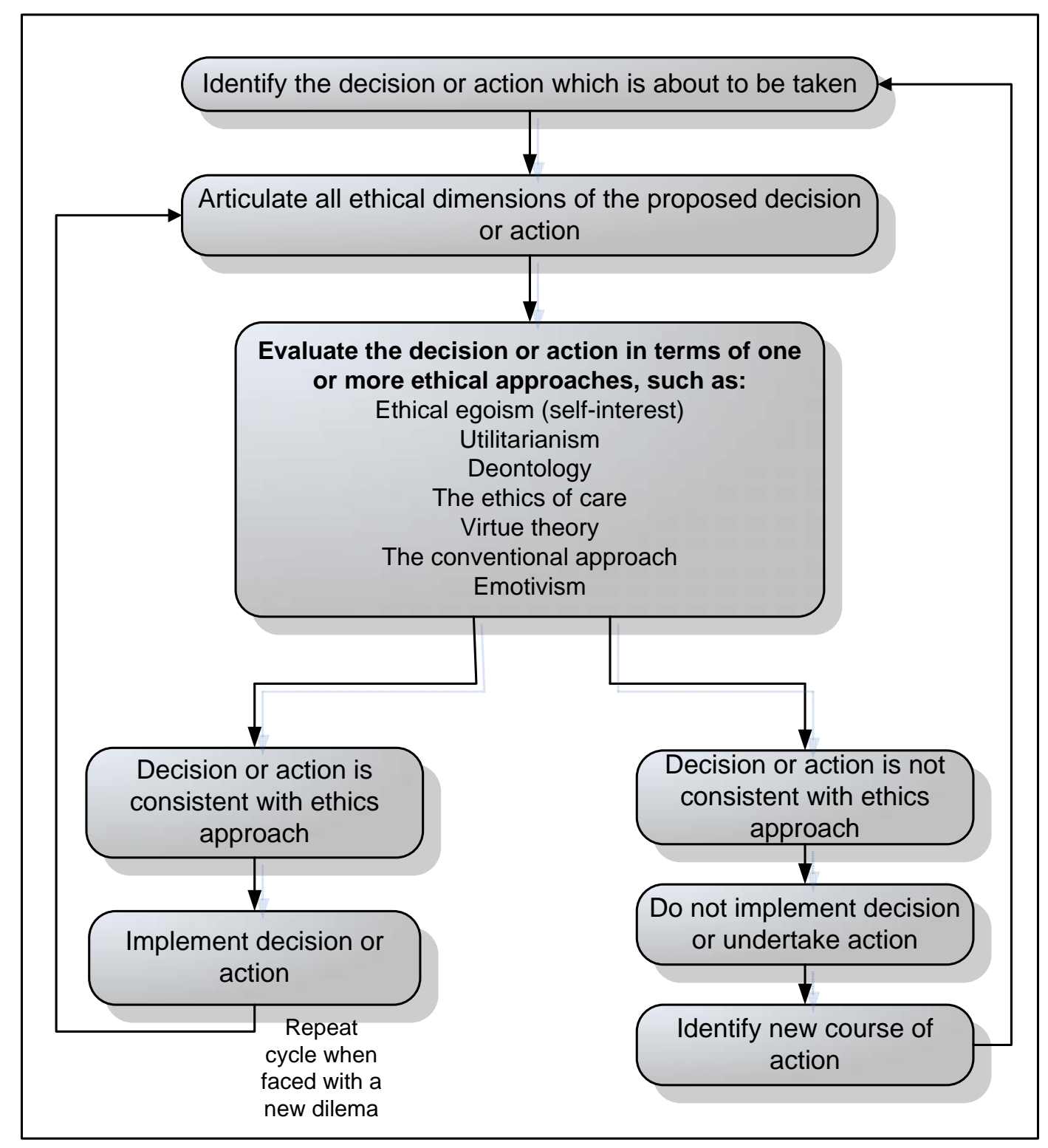

Figure 2: A generic model of ethical decision making

Source: Adapted from Carroll and Bucholtz (2000:157). 
According to the process set out in Figure 2, an investor has to articulate all the ethical dimensions of a proposed decision or action. Next he/she is required to evaluate the acceptability of the proposed decision or action in terms of the norms or standards proposed by one or more ethical approaches. Carroll and Bucholtz (2000:157) stress that the investor has the freedom to determine the approach or combination of approaches to be used as ethical guidelines.

If the proposed outcome of the decision or action is not consistent with the selected norms of acceptability, the investor should not implement the decision or undertake the action. The investor should rather consider new investment opportunities and submit them to the same process. On the other hand, if the decision maker has determined that a proposed decision or action is ethical he/she should engage in it and only repeat the cycle when faced with a new ethical dilemma.

A vital step in the ethical decision making process is that of setting norms according to one or more ethical approaches. Several of these approaches exist but only seven ones will be highlighted, namely ethical egoism, utilitarianism, deontology, the ethics of care, virtue theory, the conventional approach and emotivism. These approaches were selected on the basis that they feature prominently in business ethics literature and research.

\section{Approaches to ethical reasoning}

The first two theories, namely ethical egoism and utilitarianism, are consequential in nature and are based on the philosophy that individuals ought to do whatever maximises good consequences, either for themselves (ethical egoism) or for those affected by their decisions (utilitarianism).

\section{Ethical egoism}

In philosophy, egoism is the theory which states that one's self is, or should be, the motivation and goal of one's own actions (Hosmer, 1994:16). Ethical egoism is a form of normative egoism which holds that the investor ought to promote the 'self' above 'others'. Egoism should be distinguished from egotism which refers to the psychological overvaluation of one's own importance or activities. Rae and Wong (1999:28) state that, although egoists consider the 'self' above 'others', it does not necessarily suggest that they are narcissists. Ethical egoism further implies that the individual might avoid actions that may help others. The litmus test for the decision maker is therefore whether the considered action, decision or behaviour serves as means to promoting self-interest.

Based on the abovementioned description of ethical egoism, it could be argued that this approach is consistent with moral investing but only a weak form thereof. The argument being that the investor takes ethical issues into consideration when evaluating potential investments but will only invest if it will also benefit him/her financially. This emphasis on the economic and financial benefits of RI serves as the basis of the United Nations' Principles for Responsible Investment (United Nations, 2006:2) and is increasingly used as motivation as to why investors should engage in RI, besides just doing the right thing.

\section{Utilitarianism}

Utilitarianism is a teleological approach and is taken from the Greek word telos, meaning, 'end'. It implies that the rightness or fairness of a decision or action can be determined by looking at its results or consequences (Rae \& Wong, 1999:30). If the consequences are good, the decision or action is thus considered ethical. Likewise if the consequences are bad, the decision or action is deemed unethical or immoral. According to Mescon, Bovée and Thill (1999:65) utilitarianism proposes a standard outside of self-interest by which to judge the ethicality of a decision and separates morality from faithfulness to a divine ordinance or obedience to rigid rules.

It could be argued that responsible investors who follow a utilitarian approach to ethics are likely to focus purely on the consequences of corporate policies and practices, including those relating to corporate social responsibility initiatives. As such, they will only invest in businesses of which the stated policies and practices will ensure the greatest good of the greatest number of stakeholders. This type of reasoning could be applied to RI screening and shareholder activism approaches but it is probably best suited to a cause-based (targeted) investing strategy. The outcomes (consequences) of cause-based investments are clearly visible in that they directly enhance the general wellbeing of disadvantaged communities.

\section{Deontological ethics}

In contrast to teleological forms of moral reasoning, deontological ethics is based on principles (Rae \& Wong, 1999:34). Deontological ethics is concerned with the moral obligations, duties or responsibilities which are inherently necessary for morality to prevail, irrespective of the ends or consequences they produce. A decision or action is therefore only deemed ethical if it conforms to moral principles. A deontologist would, for example, say that theft is wrong, irrespective of who benefits from it. The classic proponent of this approach is Immanuel Kant (1724-1804) who sought to construct a system in which moral absolutes could be formulated without any recourse to religious authority. He strongly believed that the consequences of actions (actutilitarianism) or how individuals feel about actions (emotivism) were irrelevant to the morality of the action (Hosmer, 1994:18).

Before deontological thinking can be applied to RI, a distinction needs to be made between two important deontological principles, namely rights and justice.

\section{The principle of rights}

A right is a justifiable claim or entitlement such as the right to life or the right not to be killed by others. Deontologists argue that, although one right can be superseded by another, more basic right, it cannot simply be overridden by utility. Stevenson (2005:68) points out that a rights perspective mainly expresses morality from the point of view of the individual, although not exclusively. For example, the 
United Nations' Universal Declaration of Human Rights (United Nations, 1948) contains collective rights such as that of entire communities (e.g. the San community of the Kalahari). A distinction should also be made between liberty rights and welfare rights.

Liberty rights imply that individuals should be free from restriction or control and that they have the right to be left alone, as long as they do not trespass against the liberty rights of others. Examples of liberty rights include the right to privacy, private property, freedom of speech and freedom of association. These rights are generally protected by legislation and are set forth in documents such as the South African Constitution and the United Nations' Universal Declaration of Human Rights (United Nations, 1948). Liberty rights also imply that individuals are to refrain from harming or interfering with others' intended course of life. These rights do not require individuals to invest time, money, energy or any other resources to assist others and by refraining from doing so they do not act unethically or irresponsibly. As such, investors have the right not to invest in an ethically or socially responsible manner. Welfare rights refer to that which is necessary to satisfy basic human needs, such as health, happiness and general wellbeing and generally fall beyond the scope of RI.

Two kinds of deontological duties can furthermore be distinguished, namely categorical duties and prima facie duties. A categorical duty, such as speaking the truth and protecting innocent life, is absolutely never to be violated. On the other hand, a prima facie duty is one which appears, at first sight to be binding, but which may, upon closer inspection, be overridden by other, stronger duties. The difficulty with prima facie duties however lies in determining which responsibilities have priority (Lantos, 2002:211). A classic example of this dilemma relates to the much-debated trade-off between maximising shareholder wealth and advancing social goals (Friedman, 1970:32; Sparkes \& Cowton, 2004:45). Given this trade-off, responsible investors are bound to encounter difficulties in prioritising ESG considerations.

\section{The principle of justice}

The principle of justice refers to a belief that all people should be treated fairly and impartially, that rules should be applied consistently, that people who harm others should be held responsible and that they should make restitution (Mescon et al. 1999:65). In this regard, Lantos (2002:214) states that people have been given just treatment when they have received what they deserve or can legitimately claim. Several types of justice can be identified although only three are pertinent to the research in question, namely distributive, compensatory and procedural justice. Carroll and Bucholtz (2000:136) point out that distributive justice, also called social justice, refers to the fair distribution of benefits and burdens and features prominently in decisions pertaining to philanthropy. Compensatory justice involves compensating an individual or group for some past injustice and underpins the current debate on BBBEE in South Africa. Lastly, procedural justice refers to fair decision making procedures, practices and agreements.
Many responsible investors employ deontological principles as guidelines in ethical decision making. Many do so unknowingly. Rae and Wong (1999:35) indicate that most religious traditions such as Judaism, Christianity and Islam are strongly rooted in deontological ethics. As such, exclusionary screens, sometimes called 'sin' screens, are deeply rooted in the principles of duty-based ethics. It could be argued that deontologically-minded responsible investors in South Africa will favour corporate policies and practices that comply with the principles of rights (both liberty and welfare) and justice (particularly distributive and compensatory justice).

\section{The ethics of care}

It is useful to introduce an overview on the ethics of care after that of utilitarianism and deontology as this approach is critical of these traditional views of morality. The care perspective builds on the work of Gilligan (1982:40) who claims that teleological and deontological ethics focus too much on the individual and on rational thought processes. Advocates of the ethics of care disagree with the traditional 'masculine' approaches to ethics which assume that morality is impartial and that everyone's interests should be considered as equally worthy (Lantos, 2002:216). In terms of the latter, any special relationships that an individual may have with particular individuals should thus be set aside when determining what the most ethical course of action would be. In contrast, the ethics of care views the decision maker as essentially relational and not individualistic.

Proponents of this approach, which is often associated with feminism, do not deny the existence of the 'self' but hold that the 'self' has relationships that cannot be separated from the self's existence. According to the ethics of care, an individual thus has an obligation to exercise special care towards those persons with whom he/she has valuable close relations, particularly relations of dependency.

It can be argued that responsible investors who make decisions based on the principle of care are likely to scrutinise firms' stakeholder relationships. This can be done by employing a positive (inclusionary) screening approach or by actively engaging with management boards on ESG issues. It can also be argued that cause-based investors, who require no more than inflation-linked returns on their investments, base their investment decisions on the principles embedded in the ethics of care.

\section{Virtue ethics}

The virtue approach to morality differs greatly from the ethical approaches discussed so far. Rae and Wong (1999:37) point out that most contemporary approaches to ethical decision making focus on doing the right thing when being confronted with a moral dilemma. The proponents of virtue ethics however hold that there is more to morality than simply doing the right thing.

Virtue theory dates back to the classic Greeks who were concerned about the means by which individuals incorporate virtues such as honesty, fairness, truthfulness and benevolence into their characters (Carroll \& Bucholtz, 
2000:138). The focus of virtue ethics is thus more on being a good and virtuous person than merely doing good deeds. In its strongest form this view of morality implies that good deeds can only be performed by good (virtuous) people.

The question could now be asked whether virtuous men and women invest in a responsible manner. With RI having been described as a form of moral investing, it could indeed be said that responsible investors are virtuous people who place a high value on honesty, fairness, truthfulness and goodwill towards human beings, animals and the ecological environment. In evaluating corporate behaviour they are likely to consider whether businesses are doing the right things but also whether they are doing them for the right reasons. Motives thus play an important role in the ethical judgements made by responsible investors using this approach to ethical decision making.

The Aristotelian notion that an individual might have to postpone immediate pleasure in order to act with virtue is particularly apt when considering the nature of RI fund performance. Research has shown that the short-term returns of RI funds are often lower than those of traditional funds and that RI funds only tend to out-perform conventional funds over the long-term (Bauer, Koedijk \& Otten, 2005:1751; Cummings 2000:90). Responsible investors therefore require patience when prioritising virtues ahead of financial rewards and should adopt a long-term orientation.

The previous five approaches to ethical decision making are strongly rooted in principles, rational thought processes and virtues (Hosmer, 1994:25). The following two approaches to ethical decision making, namely the conventional approach and emotivism, are quite different in that they place more emphasis on the feelings and perceptions of individuals than on universal principles or rights. Both approaches draw on Stoic philosophy which espouses the notion of relativism where 'good' and 'bad' behaviours are not universally true and may differ from one society or individual to the next.

\section{The conventional approach to ethics}

An individual following the conventional approach to ethical decision making will compare a proposed decision or action against prevailing norms of acceptability in his/her society before making a decision (Carroll \& Bucholtz, 2000:102). This approach is called the conventional approach, as benchmark norms are believed to reflect the general (or conventional) views of society. This approach implies that responsible investors in a specific country will consider the prevailing trends in RI in that country at any given point in time.

According to Carroll and Bucholtz (2000:100), the greatest danger of the conventional approach lies in the subjective nature of the prevailing social norms. This opens the door to cultural relativism where 'good' means 'socially approved' in a given society or culture. Prevos (2004:1), explains that a social relativist will view certain forms of behaviour as wrong in cultures which prohibit them and right in cultures which permit them. As such, advocates of cultural relativism argue that there are no absolute grounds on which to assess moral claims within different societies, as they are all right in their own cultural context.

Gensler (1998:12) points out that the members of a society generally agree at very high levels of abstraction that certain behaviours are right or wrong but that consensus tends to disintegrate as one moves from abstract to specific situations. Subsequently, two different people could consider the same decision and action, compare it with their understanding of what the prevailing social norms are and reach different conclusions as to whether it is ethical or not. Another danger of using prevailing social norms lies in determining whether these norms are truly right or justifiable. The use of discriminatory policies practised under the previous government in South Africa serves as a case in point.

Despite the concerns regarding cultural relativism, the conventional approach is none-the-less useful in describing some of the 'prevailing themes' used by responsible investors. The most common RI themes in South Africa include the promotion of BBBEE, the provision of social infrastructure and labour related issues such as education, training and HIV/AIDS (Viviers, 2007).

\section{Emotivism}

As a non-cognitive approach, emotivism proposes that personal feelings are the most important determinants of right and wrong behaviour. However, since feelings differ from person to person, morality quickly breaks down to a matter of personal preference and subjectivism. Rae and Wong (1999:33) state that many of the same criticisms of cultural relativism apply to emotivism.

RI is sometimes referred to as 'feel good investing' hinting at the application of an emotivist approach to RI decision making (Middelton, 2003; Barringer, 2006:2). It is however not foreseen that this approach to ethical decision making will become operational among investors, whether in South Africa or further afield, for the simple reason that prudence usually supersedes emotions in investment related matters.

\section{Summary of ethical approaches and their applicability to RI}

It should be clear from the above discussion that responsible investors could gain valuable insights into moral matters by comparing their decisions and actions against the norms of acceptability proposed by one or more of the approaches described. Table 2 presents an overview of the key features of these approaches along with their application to RI.

\section{Summary and conclusions}

This research endeavoured to position RI within an appropriate ethical framework given a wider adoption of RI strategies both globally and in South Africa. Having scrutinised the definition of ethics, different types of investment ethics and several approaches to ethical decision making, it is clear that the practice of RI is strongly rooted in the topics mentioned. From the evidence presented it can be argued that responsible investors exhibit relatively high 
levels of moral development in that they generally express a concern for universal principles which exceed the prescriptions of the law.

It can further be shown that South Africa's socio-political history had a pronounced effect on the ethical approaches used by local responsible investors in evaluating investment opportunities. An analysis of the investment objectives of local RI funds indicates that preference is given to the principles underlying deontological ethics as well as the ethics of care. RI strategies which are based on deontological principles therefore tend to focus on the protection of human rights and equality as well as the promotion of distributive and compensatory justice. Responsible investors who base their investment decision on the principles underlying the ethics of care are likely to scrutinise local companies' stakeholder relations, particularly those with their employees' and local communities. Certain cause-based (targeted) investments aimed at empowering previously disadvantaged communities could also be premised on the notion of care.

Table 2: Summary of ethical approaches to ethical decision making and their application to RI

\begin{tabular}{|c|c|c|}
\hline $\begin{array}{l}\text { Ethical approach } \\
\text { to decision making }\end{array}$ & Key features & Application to RI \\
\hline Ethical egoism & $\begin{array}{l}\text { - } \quad \text { Concerned with decisions and actions that will } \\
\text { promote self-interest. } \\
\text { - } \quad \text { Might avoid actions that may help others. }\end{array}$ & $\begin{array}{ll}\text { - } & \text { Responsible investors will only invest in RIs if it } \\
\text { promotes self interest. } \\
\text { - } \quad \text { Represents a weak form of moral investing. }\end{array}$ \\
\hline Utilitarianism & 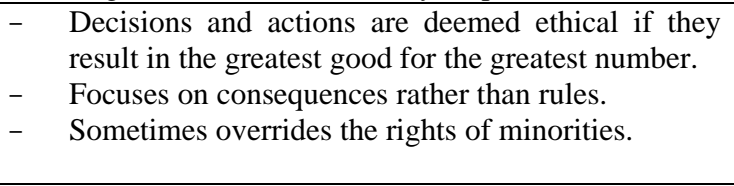 & $\begin{array}{l}\text { - Positive screening and cause-based investment } \\
\text { strategies are favoured by utilitarian investors as the } \\
\text { consequences of these strategies directly or } \\
\text { indirectly increase the general happiness of corporate } \\
\text { stakeholders and society at large. }\end{array}$ \\
\hline Deontology & $\begin{array}{l}\text { - Concerned with the moral principles, obligations, } \\
\text { duties, rights and responsibilities. } \\
\text { - } \quad \text { Principles to be respected irrespective of the ends } \\
\text { or consequences they produce. } \\
\text { - } \quad \text { Ignores circumstances. } \\
\text { - } \quad \text { Provides no hierarchy of responsibilities. }\end{array}$ & $\begin{array}{l}\text { - Deontological thinking forms the foundation of } \\
\text { faith-based exclusionary screens as well as other RI } \\
\text { strategies concerned with the protection of rights and } \\
\text { social justice. }\end{array}$ \\
\hline The ethic of care & $\begin{array}{l}\text { - Focuses on nurturing close relations, particularly } \\
\text { relations of dependency (i.e. key stakeholders) } \\
\text { - Decision makers are seen as essentially relational } \\
\text { and not individualistic. }\end{array}$ & 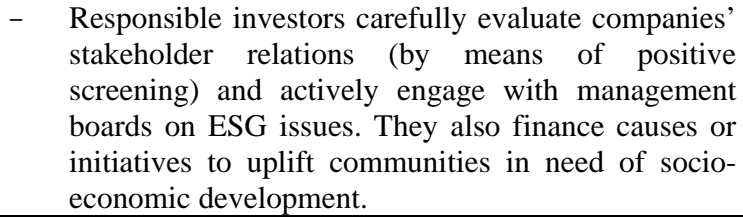 \\
\hline Virtue ethics & 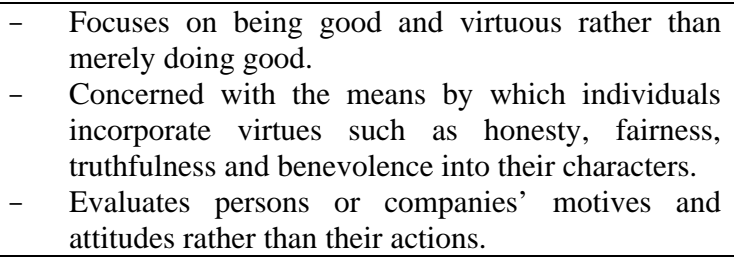 & 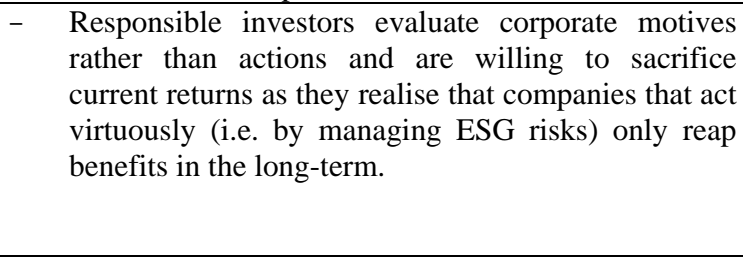 \\
\hline $\begin{array}{l}\text { The conventional } \\
\text { approach }\end{array}$ & $\begin{array}{ll}\text { - } & \text { Decisions and actions are benchmarked against } \\
\text { prevailing social norms of acceptability. } \\
\text { - } \quad \text { Culturally relative. }\end{array}$ & 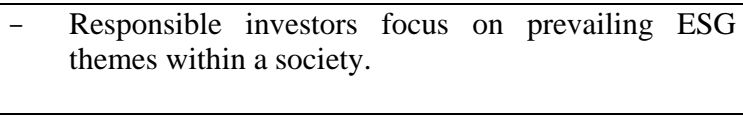 \\
\hline Emotivism & $\begin{array}{ll}\text { - } & \text { Personal feelings determine decisions regarding } \\
\text { right and wrong. } \\
\text { - } \quad \text { Culturally relative. }\end{array}$ & - $\quad$ RI seen as ‘feel good’ investing. \\
\hline
\end{tabular}

Source: Researchers' own construct.

The researchers are not in favour of recent trends in RI, such as the United Nations' Principles for Responsible Investment, which tend to downplay the importance of ethical considerations (including ethical investing which centres on the use of faith-based exclusionary screens). The main argument in favour of this approach is that not all responsible investors want to change the world. Hamilton, Jo and Statman (1993:62) state that the dean of a Quaker college was once asked why his college shunned investments in weapon manufacturers. 'Did the board of trustees think they could to stop the armaments build-up in the USA?' The dean responded by saying: 'No. Our board isn't out to change the world. We're only seeking a oneness between ourselves and our Lord'. This type of reasoning expressed by faith-based investors should be respected.

Furthermore, the United Nations' suggestion that RI practices be more widely adopted by global institutional investors merely to mitigate the adverse financial implications of ESG risks is only justifiable when due consideration is given to the role of ethics in the investment process. 


\section{Acknowledgements}

The authors wish to thank the National Research Foundation (Thuthuka Programme) and the Nelson Mandela Metropolitan University for their financial support of this research project.

\section{References}

Alexander Forbes Asset Consultants Targeted Development Investment Vehicles Manager Watch Survey September 2006. 2006. [online]

URL:http://www.aforbes.co.za/AfricaFinancial/financial_as setcons.htm .

Barringer, F. 2006. 'Feel-good investing with profits, too,' New York Times, 17 May: 1-3, [online] URL:http://www.innovestgroup.com/pdfs/2006-0517_NYT_Feel_Good_Investing.pdf.

Bauer, R., Koedijk, K. \& Otten, R. 2005. 'International evidence on ethical mutual fund performance and investment style', Journal of Banking \& Finance, 29(7): 1751-1767.

Bodie, Z., Kane, A. \& Marcus, A.J. 2002. Investments. $5^{\text {th }}$ Edition. Boston: McGrawHill.

Carroll, A.B. \& Bucholtz, A.K. 2000. Business and society: Ethics and stakeholder management. New York: South Western.

Collis, J. \& Hussey, R. 2003. Business research - a practical guide for undergraduate and postgraduate students. $2^{\text {nd }}$ Edition. Palgrave Great Britain: Macmillan.

Cowton, C. 1998. 'Socially responsible investment', Encyclopaedia of Applied Ethics, 4: 181-190.

Cranston, S. 2004. 'Too much money, too few deals', Financial Mail, 13 August, [online] URL:http://free financialmail.co.za/report04/sanlam04/msan lam.htm

Cummings, L.S. 2000. 'The financial performance of ethical investment trusts: An Australian perspective', Journal of Business Ethics, 25(1): 79-92.

De Cleene, S. \& Sonnenberg, D. 2004. Socially responsible investment in South Africa. $2^{\text {nd }}$ Edition. Johannesburg: African Institute of corporate citizenship, pp.1-49.

De Jongh, D., Ndlovu, R., Coovadia, C. \& Smith, J. 2007.

The state of responsible investment in South Africa. Pretoria: UNISA Centre for Corporate Citizenship. [online]

URL:http://www.unepfi.org/fileadmin/documents/The_State _of_Responsible_Investment_01.pdf.

Friedman, M. 1970. 'The social responsibility of business is to increase its profits', New York Times Magazine, 13 Sep 1970: 32-33 \& 122-126.
Gensler, H.J. 1998. Ethics - a contemporary introduction. London: Routledge.

Gilligan, C. 1982. In a different voice: Psychological theory and women's development. Cambridge: Harvard University Press.

Guay, T., Doh, J.P. \& Sinclair, G. 2004. 'Non-governmental organizations, shareholder activism and socially responsible investments: ethical, strategic and governance implications', Journal of Business Ethics, 52(1): 125-139.

Hamilton, S., Jo, H. \& Statman, M. 1993. 'Doing well while doing good? The investment performance of socially responsible mutual funds', Financial Analysts Journal, 49(6): 62-66.

Holland, T. 2002. 'Ethics pay in the long run', Far Eastern Economic Review, 165(15): 49-51.

Hosmer, L.T. 1994. 'Strategic planning as if ethics mattered’, Strategic Management Journal, 15(Special Issue, Summer): 17-34.

Hussein, K. \& Omran, M. 2005. 'Ethical investment revisited: Evidence from Dow Jones Islamic Indexes', The Journal of Investing, 14(3): 105-124.

Kalideen, N. 2004. 'Bank makes it easier for Muslim clients to buy cars’, Star, 7 May: 3.

Knoll, M.S. 2002. 'Ethical screening in modern financial markets: The conflicting claims underlying socially responsible investment', The Business Lawyer, 57(2): 681726.

Lantos, G.P. 2002. 'The ethicality of altruistic corporate social responsibility', Journal of Consumer Marketing, 19(3): 205-230.

Mescon, M., Bovée, C. L. \& Thill, J. V. 1999. Business today. New Jersey: Prentice Hall.

Middelton, T. 2003. 'Feel-good investing? I'd rather make money', Mutual Funds, [online] URL: http://www moneycentral msn.com/content/P57461.asp.

Mitchell, P. \& Larson, T. 2006. 'Trends report'. Social Investment Forum, 24 January, [online] URL:http://www.socialinvest.org/areas/news/2005Trends.ht $\mathrm{m}$.

Petersen, F. 2005. 'Targeted and profitable', Financial Mail, 10 June, [online]

URL:http://www.free.financialmail.co.za/report05/fmfmjun 05/dfm htm

Prevos, P. 2004. 'Ethical relativism'. Unpublished course material. Monash University, Melbourne, Australia.

Rae, S.B. \& Wong, K.L. 1999. Beyond integrity: A JudeoChristian approach to business ethics. Grand Rapids, Michigan: Harper Collins. 
Rossouw, G.J. 2002. Business ethics in Africa. $2^{\text {nd }}$ Edition. Cape Town: Oxford University Press.

Rossouw, G.J. 2004. Business ethics. $3^{\text {rd }}$ Edition. Cape Town: Oxford University Press.

Schueth, S. 2003. 'Socially responsible investing in the United States’, Journal of Business Ethics, 43(3): 189-194.

Smit, P.J. \& Cronjè, G.J. de J. 1997. Management principles: A contemporary edition for Africa. $2^{\text {nd }}$ Edition. Kenwyn: Juta.

Sparkes, R. \& Cowton, C.J. 2004. 'The maturing of socially responsible investments: A review of the developing link with corporate social responsibility', Journal of Business Ethics, 52(1): 45-57.

Stevenson, J. 2005. The complete idiot's guide to philosophy. $3^{\text {rd }}$ Edition. London: Alpha.

Sullivan, R. \& Mackenzie, C. (Eds.). 2006. Responsible investment. Sheffield, UK: Greenleaf Publishing.

United Nations. 2006. United Nations' Principles for Responsible Investment 2006. [online]

URL:http://www.unpri.org/about

United Nations. 1984. United Nations' Universal Declaration of Human Rights. [online]

URL:http://www.un.org/Overview/rights html

Viviers, S. 2007. 'A critical assessment of socially responsible investing in South Africa'. Unpublished DCom thesis. Nelson Mandela Metropolitan University, Port Elizabeth.

White, M.A. 1995. 'The performance of environmental mutual funds in the United States and Germany: Is there economic hope for "green" investors?', Research in Corporate Social Performance and Policy, (Supplement 1): 323-344. 